Table 1. Disease Activity Among Patients With PsA at Enrollment Stratified by Presence of Nail Psoriasis

\begin{tabular}{|c|c|c|c|}
\hline Characteristic* & $\begin{array}{l}\text { With Nail PsO } \\
(\mathrm{N}=1152)\end{array}$ & $\begin{array}{c}\text { Without Nail } \\
\text { PsO } \\
\text { (N = 1689) }\end{array}$ & $P$ Value $^{\dagger}$ \\
\hline Nail PsO (VAS 0-100) & $18.9(22.5)[1152]$ & $0[1689]$ & - \\
\hline Tender joint count $(0-68)$ & $6.0(9.9)[1127]$ & $3.5(7.1)[1639]$ & $<0.01$ \\
\hline Swollen joint count (0-66) & $2.4(4.4)[1125]$ & $1.7(3.5)[1639]$ & $<0.01$ \\
\hline $\mathrm{MDA}, \mathrm{n} / \mathrm{m}(\%)^{\mathrm{t}}$ & $359 / 1027(35.0)$ & $716 / 1503(47.6)$ & $<0.01$ \\
\hline DAPSA & $18.1(15.7)[643]$ & $13.4(12.4)[994]$ & $<0.01$ \\
\hline DAPSA group, $n(\%)$ & $n=643$ & $n=994$ & $<0.01$ \\
\hline Remission & $90(14.0)$ & $232(23.3)$ & \\
\hline Low & $231(35.9)$ & $402(40.4)$ & \\
\hline Moderate & $195(30.3)$ & $247(24.8)$ & \\
\hline High & $127(19.8)$ & $113(11.4)$ & \\
\hline PASDAS & $3.8(1.6)[619]$ & $3.3(1.5)[972]$ & $<0.01$ \\
\hline PASDAS group, $n(\%)$ & $n=619$ & $n=972$ & $<0.01$ \\
\hline Inactive & $215(34.7)$ & $465(47.8)$ & \\
\hline Moderate & $132(21.3)$ & $227(23.4)$ & \\
\hline Active & $228(36.8)$ & $239(24.6)$ & \\
\hline Very active & $44(7.1)$ & $41(4.2)$ & \\
\hline Enthesitis, n/m (\%) & $319 / 1152(27.7)$ & $287 / 1689(17.0)$ & $<0.01$ \\
\hline SPARCC Enthesitis Index (1-16) & $3.8(2.9)[319]$ & $3.5(2.8)[287]$ & 0.14 \\
\hline Dactylitis, $\mathrm{n} / \mathrm{m}(\%)$ & $\frac{0.01 / 2.0101}{140 / 1152(12.2)}$ & $125 / 1689(7.4)$ & $\frac{0.14}{<0.01}$ \\
\hline Dactylitis count (1-20) & $2.4(2.3)[140]$ & $2.2(1.8)[125]$ & 0.50 \\
\hline BSA, \% affected & $7.9(14.8)[1125]$ & $3.5(7.6)[1636]$ & $<0.01$ \\
\hline BSA (categorical), $n(\%)$ & $n=1125$ & $n=1636$ & $<0.01$ \\
\hline No disease $(0 \%)$ & $201(17.9)$ & $583(35.6)$ & \\
\hline Mild disease $(>0 \%$ to $\leq 3 \%)$ & $469(41.7)$ & $680(41.6)$ & \\
\hline Moderate disease $(>3 \%$ to $\leq 10 \%)$ & $258(22.9)$ & $254(15.5)$ & \\
\hline Severe disease $(>10 \%)$ & $197(17.5)$ & $119(7.3)$ & \\
\hline \multicolumn{4}{|c|}{$\begin{array}{l}\text { BSA, body surface area; DAPSA, Disease Activity in Psoriatic Arthritis; MDA, minimal disease activity; } \\
\text { PASDAS, Psoriatic Arthritis Disease Activity Score; PsO, psoriasis; SPARCC, Spondyloarthritis Research } \\
\text { Consortium of Canada; VAS, visual analog scale. } \\
\text { - All values were calculated based on available data and are presented as "mean (SD) [n]" unless otherwise } \\
\text { stated. } \\
t t \text {-test or Wilcoxon rank-sum test for continuous variables and } x^{2} \text { or Fisher's exact test for categorical } \\
\text { variables. } \\
{ }^{2} \mathrm{MDA} \text { is defined as 'yes' if a patient met at least } 5 \text { of the } 7 \text { following categories: tender joint count } \leq 1 \text {, } \\
\text { swollen joint count } \leq 1 \text {, body surface area } \leq 3 \% \text {, patient pain VAS } \leq 15 \text {, patient global activity visual } \\
\text { analogue scale } \leq 20 \text {, health assessment questionnaire } \leq 0.5 \text {, and tender entheseal points } \leq 1 \text {. }\end{array}$} \\
\hline
\end{tabular}

Table 2. Patient-Reported Outcome Measures Among Patients With PsA at Enrollment Stratified by Presence of Nail Psoriasis

\begin{tabular}{|c|c|c|c|}
\hline Characteristic ${ }^{*}$ & $\begin{array}{l}\text { With Nail PsO } \\
\quad(N=1152)\end{array}$ & $\begin{array}{c}\text { Without Nail } \\
\text { PsO } \\
\text { (N = 1689) }\end{array}$ & $P$ Value $^{\dagger}$ \\
\hline Patient pain (VAS 0-100) & $41.7(30.1)[1081]$ & $36.1(29.1)[1603]$ & 0.01 \\
\hline ue (VAS 0-100) & 135] & $39.0(29.6)[1661]$ & 0.01 \\
\hline $\begin{array}{l}\text { Patient global assessment of arthritis (VAS } \\
0-100 \text { ) }\end{array}$ & $41.8(29.5)[1132]$ & $38.0(30.1)[1663]$ & $<0.01$ \\
\hline $\begin{array}{l}\text { Patient global assessment of arthritis and } \\
\text { psoriasis (VAS } 0-100)\end{array}$ & $41.6(29.0)[1130]$ & $37.4(30.0)[1659]$ & $<0.01$ \\
\hline Mornin & & & \\
\hline & & & \\
\hline & & 104 & \\
\hline $\mathrm{HAQ}(0$ & $0.7(0$. & $0.6(0.6)[1613]$ & $<0.01$ \\
\hline & & & $<0.01$ \\
\hline EQ VAS $(0-100)$ & 68.6 & 72.1 & 0.01 \\
\hline \multicolumn{4}{|l|}{ WPAI domains } \\
\hline Current emp & & 1.3) & 0.93 \\
\hline$\%$ Work & 9) $[575]$ & $4.6(14.9)[868]$ & 0.26 \\
\hline$\%$ Impai & 3.8) $[605]$ & 3.1) $[929]$ & \\
\hline$\% 0$ & & 839] & 0.02 \\
\hline$\%$ Activity impairment & $32.5(30.2)[1026]$ & $26.6(28.0)[1543]$ & $<0.01$ \\
\hline \multicolumn{4}{|c|}{ 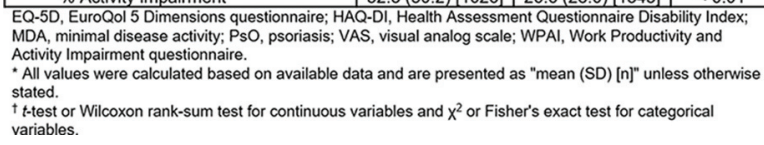 } \\
\hline
\end{tabular}

None declared, Blessing Dube Employee of: B. Dube is an employee of Corrona, LLC., Meghan Glynn Employee of: M. Glynn is an employee of Corrona, LLC., Alexis Ogdie Grant/research support from: (To my university) Novartis, Pfizer, Grant/research support from: Novartis, Pfizer, Grant/research support from: Novartis, Pfizer, Grant/research support from: Novartis, Pfizer, Consultant for: AbbVie, Bristol-Myers Squibb, Celgene, Corrona, Eli Lilly and Company, Novartis, Pfizer, and Takeda, Consultant for: AbbVie, Amgen, Bristol-Myers Squibb, Celgene, Corrona, Eli Lilly, Novartis, Pfizer Inc, Takeda, Consultant for: Abbvie, Amgen, BMS, Celgene, Corrona, Lilly, Novartis, Pfizer, Takeda, Consultant for: Abbvie, Amgen, BMS, Celgene, Corrona, Lilly, Novartis, Pfizer, Takeda

DOI: 10.1136/annrheumdis-2019-eular.1038

\section{SAT0389 INHIBITIONOF RADIOGRAPHIC PROGRESSION WAS ACHIEVED WITH INTRAVENOUS GOLIMUMAB IN ACTIVE PSA PATIENTS REGARDLESS OF CHANGES IN COMPOSITE INDICES OF DISEASE ACTIVITY IN A PHASE III TRIAL}

Philip J. Mease $^{1}$, M Elaine Husni ${ }^{2}$, Shelly Kafka ${ }^{3}$, Soumya D. Chakravarty ${ }^{3,4}$, Diane D. Harrison ${ }^{5}$, Kim Hung Lo ${ }^{5}$, Stephen $\mathrm{Xu}^{5}$, Elizabeth C. Hsia, ${ }^{5,6}$,

Arthur Kavanaugh'. ' Swedish Medical Center and Univ of Wash School of Med, Seattle, United States of America; ${ }^{2}$ Cleveland Clinic, Cleveland, United States of America; ${ }^{3}$ Janssen Scientific Affairs, LLC, Horsham, United States of America; ${ }^{4}$ Drexel Univ College of Med, Phila, United States of America; ${ }^{5}$ Janssen Research and Development, LLC, Spring House, United States of America; ${ }^{6}$ Univ of Penn Medical Center, Phila, United States of America; ${ }^{7}$ Univ of CA San Diego, San Diego, United States of America

Background: GO-VIBRANT is a Phase 3 trial of intravenous (IV) golimumab (GLM), an anti-tumor necrosis factor alpha (TNF $\alpha$ ) monoclo nal antibody, in adult patients (pts) with active psoriatic arthritis (PsA).

Objectives: To assess if changes in Disease Activity in PsA (DAPSA), PsA Activity Score (PASDAS), Minimal Disease Activity (MDA), Very Low Disease Activity (VLDA), and Clinical Disease Activity Index (CDAI) meas ures correlate with $\mathrm{X}$-ray progression.

Methods: In this multicenter, randomized, double-blind, placebo (PBO)controlled trial, 480 bionaïve PsA pts with active disease $(>5$ swollen $\& \geq 5$ tender joints, C-reactive protein $\geq 0.6 \mathrm{mg} / \mathrm{dL}$, active plaque psoriasis or documented history despite treatment w/csDMARDs \&/or NSAIDs) received IV GLM $2 \mathrm{mg} / \mathrm{kg}(\mathrm{N}=241)$ at Wks0/4 then q8wks or PBO $(\mathrm{N}=239)$ at $W k s 0 / 4 / 12 / 20$ with crossover to $G L M$ at Wk24. In a post-hoc analysis, association of disease activity measures DAPSA, PASDAS, MDA, VLDA, \& CDAI with X-ray progression was examined. Total modified van der Heijde-Sharp (vdH-S) score assessed X-ray progression at Wks $0 / 24 / 52$. Last observation carried forward imputation was used for partially missing data \& non-responder imputation for missing data. Nominal p-values are reported without multiplicity adjustment.

Results: Mean changes from baseline in vdH-S scores were lower with GLM than PBO at Wk24 $(-0.36$ vs 1.95 , respectively, $\mathrm{p}<0.001)$ and at Wk52 after crossover from PBO to GLM arm (-0.49 vs 0.76). Changes in all disease activity measures appeared to correlate with X-ray progression (Table). GLM-treated pts had less X-ray progression regardless of disease activity measure. GLM treated pts in remission or with low disease activity tended to have less X-ray progression at Wk52 vs pts with moderate or high disease activity (mean change in $\mathrm{vdH}-\mathrm{S}$ : DAPSA remission or low disease activity -0.88 , moderate activity -0.48 , high disease activity 0.41 ). Similar patterns were seen with PASDAS and CDAI (Table). Irrespective of level of disease activity, GLM-treated pts from Wk 0-52 tended to have less X-ray progression vs PBOtreated pts who switched to GLM at Wk24 (mean change in vdH-S 052 wk GLM vs PBO $\rightarrow$ GLM: DAPSA remission or low disease activity 0.88 vs 1.49 , moderate activity -0.48 vs 1.38 , high disease activity 0.41 vs 1.27 )

Interestingly, pts treated with GLM who did not achieve MDA or VLDA by $\mathrm{Wk} 52$ also tended to have less $\mathrm{X}$-ray progression vs PBO pts (mean change no MDA GLM 0.03 vs PBO 1.50; $p=0.0011$ and mean change no VLDA GLM -0.30 vs PBO 1.45; p<0.0001).

Conclusion: In this analysis, all disease activity measures generally correlated with X-ray progression from baseline to Wk24 and to Wk52. Higher disease activity was associated with increased X-ray progression. GLMtreated pts not achieving MDA \& VLDA at Wk52 tended to have less $X$ ray progression vs $\mathrm{PBO} \rightarrow \mathrm{GLM}$ pts. GLM's ability to inhibit $\mathrm{X}$-ray progression, despite pts not being in clinical remission or low disease activity, illustrates an example of "disconnect" between clinical outcomes \& X-ray progression seen in other studies.

Disclosure of Interests: Philip J Mease Grant/research support from: AbbVie, Amgen, BMS, Celgene, Janssen, Lilly, Novartis, Pfizer, SUN and UCB, Consultant for: AbbVie, Amgen, BMS, Galapagos, Gilead Sciences, 


\begin{tabular}{|c|c|c|c|c|}
\hline \multicolumn{5}{|c|}{$\begin{array}{l}\text { Table. Mean change from baseline (SD) in total modified vdH-S score stratified by CDAl, DAPSA, } \\
\text { PASDAS, MDA, and VLDA in PsA patients from GO-VIBRANT }\end{array}$} \\
\hline & \multicolumn{2}{|c|}{ Baseline to Wk24 } & \multicolumn{2}{|c|}{ Baseline to Wk52 } \\
\hline & PBO & GLM $2 \mathrm{mg} / \mathrm{kg}$ & $\mathrm{PBO} \rightarrow \mathrm{GLLM} 2^{2}$ & GLM $2 \mathrm{mg} / \mathrm{kg}$ \\
\hline \multicolumn{5}{|l|}{ DAPSA } \\
\hline Remission-low disease activity $(\leq 14), n$ & 10 & 107 & 105 & 119 \\
\hline $\begin{array}{l}\text { Mean change (SD) } \\
\text { p-value }\end{array}$ & $-0.05 \pm 2.14$ & $\begin{array}{c}-0.64+1.66 \\
0.4422\end{array}$ & $1.49 \pm 4.96$ & $-0.88 \pm 2.34$ \\
\hline Moderate disease activity $(>14-28), n$ & 37 & 59 & 66 & \\
\hline $\begin{array}{l}\text { Mean change (SD) } \\
\text { p-value }\end{array}$ & $0.29 \pm 1.81$ & $\begin{array}{l}-0.32+1.54 \\
0.0268\end{array}$ & $1.38 \pm 4.16$ & $-0.48 \pm 1.82$ \\
\hline Active disease activity $(>28), n$ & 190 & 71 & 66 & 54 \\
\hline Mean change (SD) & $1.77 \pm 3.56$ & $0.21+1.97$ & $1.27 \pm 4.36$ & $0.41+3.30$ \\
\hline \multirow{2}{*}{\multicolumn{5}{|c|}{ PASDAS }} \\
\hline & & & & \\
\hline $\begin{array}{l}\text { Inactive disease activity }(\leq 3.2), \mathrm{n} \\
\text { Mean change (SD) }\end{array}$ & 12 & 101 & 114 & 118 \\
\hline $\begin{array}{l}\text { Mean change (SD) } \\
\text { p-value }\end{array}$ & $-0.17 \pm 2.136$ & $\begin{array}{c}-0.64+1.729 \\
0.4305\end{array}$ & $1.53 \pm 4.850$ & $\begin{array}{c}-1.01+2.384 \\
<0.0001\end{array}$ \\
\hline Moderate disease activity $(>3.2 \&<5.4), n$ & 85 & 109 & 83 & 83 \\
\hline Mean change (SD) & $0.73 \pm 1.926$ & $-0.16 \pm 1.750$ & $1.14 \pm 3.727$ & $-0.20 \pm 1.965$ \\
\hline $\begin{array}{l}\text { p-value } \\
H \text {-valu }\end{array}$ & & 0.0003 & & 0.0055 \\
\hline $\begin{array}{l}\text { Mean change (SD) } \\
\text { (SD) }\end{array}$ & $2.29 \pm 4.107$ & $0.47 \pm 1.891$ & $3.81+7.052$ & $0.54 \pm 3.066$ \\
\hline $\mathrm{p}$-value & & 0.0290 & & 0.1122 \\
\hline \multicolumn{5}{|l|}{ MDA } \\
\hline Yes, $n$ & 11 & 78 & 80 & 101 \\
\hline $\begin{array}{l}\text { Mean change (SD) } \\
\text { p-value }\end{array}$ & $0.91+2.49$ & $\begin{array}{c}-0.83 \pm 1.78 \\
0.0232\end{array}$ & $1.19 \pm 3.86$ & $\begin{array}{l}-1.16 \pm 2.46 \\
<0.0001\end{array}$ \\
\hline No, $n$ & 226 & & 157 & 136 \\
\hline Mean change (SD) & $1.49 \pm 3.39$ & $-0.05 \pm 1.70$ & $1.50 \pm 4.90$ & $0.03 \pm 2.44$ \\
\hline \multirow{2}{*}{\multicolumn{5}{|c|}{ VLDA }} \\
\hline & 1 & 16 & & \\
\hline $\begin{array}{l}\text { Mean change (SD) } \\
\text { p-value }\end{array}$ & 0 & $\begin{array}{l}-0.91+1.04 \\
0.3749\end{array}$ & $0.91+3.32$ & $-1.49+2.22$ \\
\hline No, n & 236 & $\begin{array}{l}0.3749 \\
221\end{array}$ & 213 & 202 \\
\hline Mean change (SD) & $1.47 \pm 3.36$ & $-0.26+1.80$ & $1.45 \pm 4.69$ & $-0.30+2.52$ \\
\hline p-value & & $<0.0001$ & & $<0.0001$ \\
\hline \multicolumn{5}{|l|}{ CDAl } \\
\hline Remission $(\leq 2,8), n$ & 5 & 43 & 58 & 63 \\
\hline $\begin{array}{l}\text { Mean change (SD) } \\
\text { p-value }{ }^{\mathrm{b}}\end{array}$ & $-0.60 \pm 1.34$ & $\begin{array}{l}-0.80 \pm 1.76 \\
0.9170\end{array}$ & $1.52 \pm 5.55$ & $\begin{array}{c}-1.06 \pm 2.41 \\
0.0003\end{array}$ \\
\hline Low disease activity $(>2.8 \& \leq 10), n$ & 28 & 98 & 78 & 92 \\
\hline $\begin{array}{l}\text { Mean change (SD) } \\
\text { p-value }\end{array}$ & $0.77 \pm 2.01$ & $\begin{array}{c}-0.41+1.43 \\
0.0011\end{array}$ & $1.21+3.59$ & $-0.81 \pm 2.12$ \\
\hline Moderate disease activity $(>10 \& \leq 22), n$ & 67 & 66 & 64 & 69 \\
\hline $\begin{array}{l}\text { Mean change (SD) } \\
\text { p-value }\end{array}$ & $0.88 \pm 2.73$ & $\begin{array}{l}-0.10+2.04 \\
0.0429\end{array}$ & $1.32+4.25$ & $\begin{array}{c}0.20 \pm 2.82 \\
0.0905\end{array}$ \\
\hline High disease activity (>22), n & 137 & 30 & 37 & 13 \\
\hline $\begin{array}{l}\text { Mean change (SD) } \\
\text { p-value }\end{array}$ & $1.96 \pm 3.79$ & $\begin{array}{c}0.30 \pm 1.95 \\
0.0079\end{array}$ & $1.75 \pm 5.34$ & $\begin{array}{c}1.11+2.65 \\
0.8144\end{array}$ \\
\hline \multicolumn{5}{|c|}{$\begin{array}{l}\text { CDAl=Clinical Disease Activity Index; DAPSA=Disease Activity in Psoriatic Arthritis score; GLM=golimumab; } \\
\text { MDA=Minimal Disease Activity; PBO=placebo; PASDAS=Psoriatic Arthritis Activity Score; PSA=active psoriatic } \\
\text { arthritis; SD=standard deviation; vdH-S=van der Heijde-Sharp; VLDA=Very Low Disease Activity } \\
\text { aPBO pts crossed over to IV GLM } 2 \mathrm{mg} / \mathrm{kg} \text { at Wk24. } \\
\text { oP-value is based on ANOVA w/Van der Waerden rank test }\end{array}$} \\
\hline
\end{tabular}

Inc., Janssen, Lilly, Novartis, Pfizer, SUN and UCB, Speakers bureau: AbbVie, Amgen, BMS, Celgene, Genentech, Janssen, Lilly, Novartis, Pfizer and UCB, M Elaine Husni Grant/research support from: Janssen, Shelly Kafka Shareholder of: J\&J, Employee of: J\&J, Soumya D Chakravarty Shareholder of: Johnson \& Johnson, Employee of: Johnson \& Johnson, Diane D Harrison Employee of: Janssen Research \& Development, LLC, Kim Hung Lo Employee of: Janssen Research \& Development, LLC, Stephen Xu Employee of: Employee of Janssen Research \& Development, LLC, Elizabeth C Hsia Employee of: Employee of Janssen Research \& Development, LLC, Arthur Kavanaugh Grant/research support from: UCB Pharma

DOI: 10.1136/annrheumdis-2019-eular.180

\section{SAT0390 GUSELKUMAB WAS MORE EFFECTIVE THAN SECUKINUMAB IN PATIENTS WITH PLAQUE PSORIASIS AND THE SUBSET OF PATIENTS WITH SELF- REPORTED PSORIATIC ARTHRITIS IN THE RANDOMIZED, DOUBLE-BLIND, HEAD-TO-HEAD COMPARISON STUDY ECLIPSE OVER 1 YEAR}

Joseph F. Merola ${ }^{1}$, LI Shu' ${ }^{2}$, Ming-Chun Hsu², Chetan Karyekar ${ }^{3}$, Susan Flavin ${ }^{2}$, Bruce Randazzo ${ }^{2}$, Laura C. Coates ${ }^{4} .^{1}$ Brigham and Women's Hospital, Harvard Med School, Boston, United States of America; ${ }^{2} J a n s s e n$ Research and Development, LLC, Spring House, United States of America; ${ }^{3}$ Janssen Medical Affairs, Horsham, United States of America; ${ }^{4}$ Oxford University, Oxford, United Kingdom

Background: Guselkumab (GUS, an antibody against IL-23) and secukinumab (SEC, an antibody against IL-17A) are both approved for the treatment of psoriasis ( $\mathrm{PsO}$ ). Up to $30 \%$ of patients with $\mathrm{PsO}$ may have psoriatic arthritis (PsA).

Objectives: The ECLIPSE study compared efficacy and safety of GUS vs SEC in patients with plaque PsO. Post hoc analyses examined outcomes in the subgroup of patients with self-reported psoriatic arthritis (PsA).

Methods: ECLIPSE was a randomized, double-blind trial of adults with moderate-to-severe plaque PsO who received GUS $100 \mathrm{mg}$ at Weeks 0 , 4 , then every 8 weeks, or SEC $300 \mathrm{mg}$ at Weeks $0,1,2,3$, and 4 , then every 4 weeks, both through Week 44 . The primary endpoint was the proportion of patients achieving $\geq 90 \%$ improvement compared to baseline in the Psoriasis Area and Severity Index (PASI) score at Week 48. Cochran-Mantel Haenszel chi-square testing stratified by investigator was used to compare treatment-group responses.

Results: Overall, treatment groups [GUS ( $n=534)$, SEC ( $n=514)$ ] were comparable at baseline: weight $89 \mathrm{~kg}, 24 \%$ body surface area $\mathrm{PsO}$, and Investigator Global Assessment (IGA) moderate $(76 \%)$ or severe $(24 \%)$. These characteristics were similar to those of subgroups with self-reported PsA [GUS $(n=97)$, SEC $(n=79)]$. In the overall population, the primary endpoint of PASI 90 response at Week 48 was achieved by $84.5 \%$ of GUS vs $70.0 \%$ of SEC patients (treatment difference $14.2[95 \%$ $\mathrm{Cl}=9.6 \%, 18.8 \%], \mathrm{P}<0.001)$. Among patients with $\mathrm{PsA}$, the primary endpoint of PASI 90 response at Week 48 was achieved by $82.5 \%$ of GUS vs $63.3 \%$ of SEC patients (treatment difference $19.2 \% \quad[95 \% \mathrm{Cl}=5.0 \%$, $33.4 \%]$ ). Beyond week 20 , in both the overall study population and the PsA subpopulation, GUS-treated patients maintained the PASI 90 response while SEC-treated patients had a reduction in response through week 48 (Figure). In the overall population, results of the first major secondary endpoint (proportion of patients with a PASI 75 response at both Week 12 and 48) showed non-inferiority of GUS vs SEC (GUS-84.6\% vs SEC-80.2\% of patients, $p<0.001$ ), but superiority was not demonstrated $(\mathrm{p}=0.062)$. Adverse events observed in the overall population and PsA subgroup were generally consistent with the established safety profiles for GUS and SEC.

Conclusion: In the subset of patients with self-reported PsA in the ECLIPSE study, GUS demonstrated better maintenance of response and higher efficacy at approximately one year compared with SEC in the treatment of moderate to severe plaque PsO. These findings were consistent with those for the overall study population of patients with plaque PsO. AEs observed were generally consistent with the established safety profiles for GUS and SEC.

Disclosure of Interests: Joseph F Merola Grant/research support from: Janssen, Shu Li Employee of: Janssen Research \& Development, LLC Ming-Chun Hsu Employee of: Janssen Research \& Development, LLC, Chetan Karyekar Shareholder of: J\&J, Employee of: Janssen Scientific

Figure. Proportion of Patients Achieving PASI 90 Response $(95 \% \mathrm{Cl})$

A.

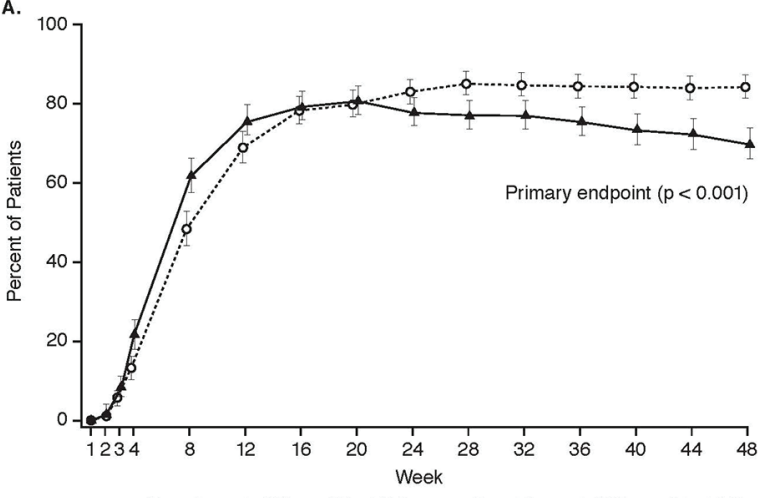

..o.. Guselkumab $100 \mathrm{mg}(\mathrm{N}=534)$ — Secukinumab $300 \mathrm{mg}(\mathrm{N}=514$

B.

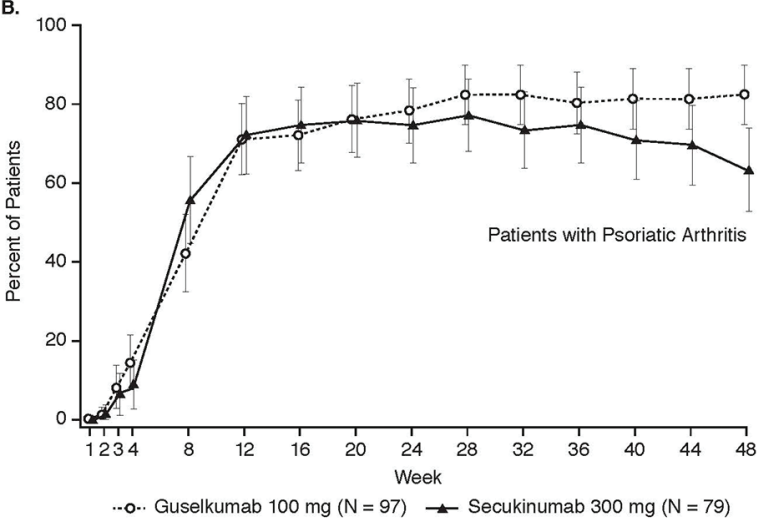

A. Total ECLIPSE population of patients with moderate to severe plaque psoriasis. B. Subgroup of patients with Psoriatic Arthritis.

Non-responder imputation was used for missing data

$\mathrm{Cl}=$ Confidence interval, PASI 90=90\% improvement in the Psoriasis Area and Severity Index (PASI). 